\title{
Analisis Pencegahan Hospital Acquired Infections (HAls) Pada Dokter Muda di Rumah Sakit Putri Hijau Medan Sumatera Utara
}

\author{
Raden Jaka Sarwadhamana ${ }^{1}$ Arifah Mu'amanah ${ }^{2}$ \\ ${ }^{1}$ Administrasi Rumah Sakit Universitas Alma Ata, Yogyakarta Indonesia \\ ${ }^{2}$ Kedokteran Universitas Islam Sumatera Utara \\ Email: jaka.sarwadhamana@almaata.ac.id
}

\begin{abstract}
Abstrak
Rumah sakit sangat rentan untuk terjadinya Hospital Acquired Infections (HAls) atau yang dikenal sebagai infeksi nosokomial, merupakan infeksi yang didapat sebagai kosekuensi dari pengasuhan tenaga kerja medis dalam menjalankan tugasnya. Pengendalian penyebaran infeksi HAls perlu dilakukan oleh rumah sakit dengan memperhatikan angka kejadian HAls karena menjadi tolak ukur mutu pelayanan Rumah Sakit. Tujuan dari penelitian ini adalah untuk mengetahui analisis upaya pencegahan Hospital Acquired Infections (HAls) di Rumah Sakit Putri Hijau Medan Sumatera Utara. Penelitian ini merupakan penelitian deskriptif kuantitatif dengan rancangan survey observasional. Populasi dalam penelitiana ini adalah seluruh dokter muda yang melakukan Coas di Rumah Sakit Putri Hijau Medan Sumatera Utara sebanyak 224 responden. Sampel dalam penelitian ini berjumlah 164 yang di ambil dengan teknik simple random sampling yaitu mengambil sampel secara acak sederhana. Data yang telah dikumpulkan kemudian dianalisis menggunakan analisis univariat. Hasil penelitian menunjukan bahwa responden sebagian besar melakukan upaya pencegahan Hospital Acquired Infections (HAls) yaitu sebanyak 90 responden (54,9\%) sedangkan yang tidak melakukan upaya pencegahan infeksi sebanyak 74 responden $(45,1 \%)$. Kesimpulan sebagian besar responden di Rumah Sakit Putri Hijau Medan Sumatera Utara patuh dalam melakukan upaya pencegahan Hospital Acquired Infections (HAls).
\end{abstract}

Kata Kunci: Hospital Acquired Infections (HAls)

\section{Analysis Hospital Acquired Infections (HAls) at young Doctor in Hospital Putri Hijau Medan North Sumatera}

\begin{abstract}
The hospital is vulnerable to the occurrence of hospital acquired infections (HAls) or known as nosocomial infections, is an infection acquired as a necessary consequence of medical parenting labor in her duties. HAls infection control the spread of hospital should be implemented by taking into account the incidence hais benchmark for quality of hospital services. This study aims to analysis hospital acquired infections (HAls) at young doctor in Hospital Putri Hijau Medan North Sumatera. This study used a descriptive quantitative research design with the survey observasional method. The sampling technique uses simple random sampling with 164 young doctor. Analyze data using univariate. The results in this study, as many as 90 respondents (54,9\%) had to prevent Hospital Acquired Infections (HAls) and as many as 74 respondents (45,1\%) respondents had not to to prevent Hospital Acquired Infections (HAls). Conclusion the majority of respondents in the hospital Putri Hijau Medan North Sumatera had to prevent Hospital Acquired Infections (HAls).
\end{abstract}

Keywords: Hospital Acquired Infections (HAls)

Received:25/08/2019; published: 1/10/2019 


\section{PENDAHULUAN}

Rumah sakit sebagai salah satu fasilitas pelayanan kesehatan yang memiliki peran sangat strategis dalam upaya mempercepat peningkatan derajat kesehatan masyarakat. Masyarakat sebagai pasien dirumah sakit sangat rentan terhadap infeksi di rumah sakit yang dapat terjadi karena tindakan perawatan selama pasien di rawat, kondisi lingkungan di sekitar rumah sakit, dan daya tahan tubuh pasien sendiri. Rumah sakit menggukan standar Joint Commision International ( $\mathrm{JCl}$ ) dalam upaya melakukan pencegahan dan pengendalian infeksi dan hal ini merupakan tantangan di dalam praktisi kesehatan dan pelayanan kesehatan (1). Infeksi merupakan efek samping yang paling umum akibat dari tinggal dirumah sakit yang mempengaruhi sekitar 5-10\% dari pasien rawat inap di negara maju dan lebih besar di negaranegara berkembang (2).

Data World Health Organization (WHO) menunjukan bahwa angka kejadian infeksi di rumah sakit sekitar 3-21\% dimana infeksi merupakan persoalan serius yang dapat menjadi penyebab langsung maupun tidak langsung kematian pasien (3). WHO juga melakukan studi prevalensi di 55 rumah sakit di 14 negara yang mencerminkan 4 region WHO (Eropa, Mediterania Timur, Asia Tenggara dan pasifik Barat), diperoleh data bahwa rata-rata 8,7\% pasien di rumah sakit Mediterania terjangkit Hospital Acquired Infections (HAls) dan setiap waktu terdapat 1,4 juta penduduk dunia menderita komplikasi akibat HAls (3). Angka kejadian HAls dari 10 Rumah Sakit Umum pendidikan di Indonesia cukup tinggi yaitu antara 6-16\% dengan rata-rata 9,8\% yang dimana seharusnya angka kejadian HAls tidak boleh lebih dari $1,5 \%$ (4). Kejadian HAls ini selain dapat menimbulkan kematian juga dapat meningkatkan lama perawatan di Rumah Sakit, biaya perawatan semakin tinggi, dan meningkatkan angka morbiditas dan mortalitas pada pelayanan kesehatan dirumah sakit (5).

Hospital Acquired Infections (HAls) atau yang dikenal sebagai infeksi nosokomial, merupakan infeksi yang didapat sebagai kosekuensi dari pengasuhan tenaga kerja medis dalam menjalankan tugasnya. Hal ini sering dikaitkan dengan lingkungan rumah sakit dan tenaga yang memberiasuhan medis (6). Infeksi nosokomial juga di definisikan sebagai infeksi yang terkena pada pasien semasa di rumah sakit maupun di fasilitas kesehatan lainnya. Kejadian infeksi yang tinggi dirumah sakit merupakan indikator pentingnya suatu usaha pengendalian infeksi. Pengendalian penyebaran infeksi HAls perlu dilakukan oleh rumah sakit dengan memperhatikan angka kejadian HAls karena menjadi tolak ukur mutu pelayanan Rumah Sakit (4).

Salah satu cara meningkatkan mutu pelayanan Rumah Sakit adalah dengan menurunkan angka kejadian HAls, sehingga dibutuhkan kerjasama dari semua tenaga kesehatan baik dokter, perawat, bidan dan tenaga kesehatan lainnya yang lebih banyak kontak dengan pasian. Salah satu pencegahan yang dapat dilakukan oleh tenaga medis yaitu dengan Indonesian Journal of Hospital Administration Vol. 2 No.2 
menghambat rute penularan bakteri dari sumber potensial dan resevoir bakteri ke orang yang tidak mengalami infeksi dengan kepatuhan mencuci tangan (7).

Berdasarkan latar belakang masalah yang telah dikemukakan diatas maka rumusan masalah yang diteliti adalah bagaimana analisis upaya pencegahan Hospital Acquired Infections (HAls) pada dokter muda di Rumah Sakit Putri Hijau Medan Sumatera Utara. Adapun tujuan dari penelitian ini adalah untuk mengetahui analisis upaya pencegahan Hospital Acquired Infections (HAls) pada dokter muda di Rumah Sakit Putri Hijau Medan Sumatera Utara

\section{BAHAN DAN METODE}

Desain penelitian ini adalah deskriptif kuantitatif dengan metode survey observasional. Penelitian ini dilakukan di Rumah Sakit Putri Hijau Medan Sumatera Utara pada Januari 2020. Populasi pada penelitian ini adalah dokter muda yang melakukan Coas di Rumah Sakit Putri Hijau Medan Sumatera Utara berjumlah 224 responden. Teknik pengambilan sampel menggunakan simple random sampling dengan jumlah responden sebanyak 164 dokter muda yang memenuhi kriteria inklusi dan eksklusi. Tahapan penelitian dilakukan dengan pengumpulan data primer dan sekunder yang menggunakan Instrumen penelitian: kuesioner upaya pencegahan Hospital Acquired Infections (HAls). Analisis data yang digunakan adalah univariat.

\section{HASIL DAN PEMBAHASAN}

Penelitian dilakukan di Rumah Sakit Putri Hijau Medan Sumatera Utara dengan jumlah responden dokter muda sebanyak 164 . Tujuan penelitian dilakukan untuk mengetahui analisis upaya pencegahan Hospital Acquired Infections (HAls) pada dokter muda di Rumah Sakit Putri Hijau Medan Sumatera Utara. Hasil penelitian disajikan sesuai dengan tujuan penelitian dan diuraikan sebagai berikut:

Tabel 1 Karakteristik Responden Penelitian

\begin{tabular}{cccc}
\hline \multicolumn{2}{c}{ Karakteristik } & $\mathbf{n}$ & $\%$ \\
\hline Jenis Kelamin & & \\
& Laki-Laki & 57 & 34,8 \\
& Perempuan & 107 & 65,2 \\
\hline Umur & 21 & & \\
& 22 & 17 & 10,4 \\
23 & 24 & 14,6 \\
24 & 32 & 19,5 \\
& 25 & 75 & 45,7 \\
& Total & 16 & 9,8 \\
\hline \multicolumn{2}{c}{}
\end{tabular}


Berdasarkan hasil penelitian yang dilakukan di Rumah Sakit Putri Hijau Medan Sumatera Utara, sebagian besar responden berjenis kelamin perempuan yaitu sebanyak 107 responden $(65,2 \%)$ sedangkan yang berjenis kelamin laki-laki sebanyak 57 responden (34,8\%). Jenis kelamin dapat mempengaruhi upaya pencegahan Hospital Acquired Infections (HAIs), karena perempuan cenderung memiliki kebiasaan pola hidup bersih (8). Perempuan memiliki sifat seperti perhatian yang lebih, penyabar, dan ulet dalam melakukan pekerjaan. Berdasarkan pengamatan yang dilakukan selama pengambilan data, peneliti melihat bahwa sebagian besar yang patuh dalam melakukan cuci tangan dalam upaya pencegahan Hospital Acquired Infections (HAls) adalah responden perempuan, dan hanya sebagin kecil responden laki-laki yang melakukan patuh melakukan cuci tangan karena masih adanya keyakinan bahwa penggunaan sarung tangan tidak membutuhkan cucitangan secara lengkap serta baik dan benar. Hal tersebut sesuai dengan hasil penelitian bahwa responden perempuan lebih patuh dalam 6 langkah mencuci tangan yaitu sebanyak 90 responden (84,1\%) dari 164 responden yang diteliti.

Hasil penelitian juga menujukan bahwa mayoritas responden di Rumah Sakit Putri Hijau Medan Sumatera Utara berusia remaja akhir yaitu 24 tahun sebanyak 75 responden (45,7\%), 23 tahun sebanyak 32 responden (19,5\%). Anwar mengungkapkan bahwa selama periode ini remaja mulai memandang dirinya sebagai orang dewasa dan mulai mampu menunjukan pemikiran, sikap, dan perilaku yang semakin dewasa (9). Hasil penelitian juga meunjukan bahwa sebagain besar responden yang berusia 24 tahun melakukan upaya penceganan Hospital Acquired Infections (HAls) dengan baik yaitu sebanyak 41 responden (54,7\%). Hasil penelitian ini sejalan dengan peneitian yang dilakukan oleh Purwanti di RSUD Arifin Achmad yang menunjukan bahwa sebagian besar responden berusia diantara 21-40 tahun $(97,6 \%)$ dari 41 responden yang diteliti (10). Semakin meningkat usia seseorang, diharapkan juga psikologis serta kedewasaannya ikut meningkat. Usia berengaruh terhadap pola fikir seseorang dan pola fikir berpengaruh terhadap perilaku seseorang. Semakin cukup usia seseorang akan semakin matang dalam berfikir dan bertindak (11), hal ini dapat mempengaruhi pengetahuan responden dalam upaya pencegahan Hospital Acquired Infections (HAls).

Tabel 2 Lima Momen Mencuci Tangan

\begin{tabular}{lc}
\hline Melakukan 5 Momen Mencuci Tangan & $\%$ \\
\hline Sebelum ke pasien & 87,19 \\
Sebelum tindakan invasif & 94,51 \\
Sesudah dari pasien & 82,92 \\
Sesudah terpapar cairan beresiko & 92,68 \\
Sesudah kontak dengan lingkungan pasien & 54,87 \\
\hline
\end{tabular}


Tabel 3 Upaya pencegahan Hospital Acquired Infections (HAls)

\begin{tabular}{lll}
\hline Upaya Pencegahan & $\mathbf{n}$ & $\%$ \\
\hline Dilakukan & 90 & 54,9 \\
Tidak dilakukan & 74 & 45,1 \\
\hline Total & 164 & 100 \\
\hline
\end{tabular}

Mencuci tangan adalah tindakan yang paling mendasar dalam upaya pencegahan Hospital Acquired Infections (HAls) dirumah sakit. Hasil penelitian yang dilakukan di Rumah Sakit Putri Hijau Medan Sumatera Utara menunjukan bahwa sebagian besar responden melakukan upaya pencegahan Hospital Acquired Infections (HAls) yaitu sebanyak 90 responden (54,9\%), sedangkan 74 responden (45,1\%) lainnya tidak melakukan upaya pencegahan Hospital Acquired Infections (HAls). Upaya pencegahan Hospital Acquired Infections (HAls) dalam penelitian ini merupakan upaya yang dilakukan oleh tenaga kesehatan (dokter muda) dalam mencegah penyebaran infeksi melalui cuci tangan.

Hasil penelitian ini sejalan dengan penelitian yang dilakukan Setiana dengan hasil bahwa sebagian besar responden dokter muda di RSUP dr. Kariadi Semarang melakukan upaya pencegahan infeksi dalam kategori baik pada kebersihan tangan $(48,1 \%)$ dan penggunaan teknik aseptik (41,7\%) dari 54 responden yang diteliti (12). Kepatuhan responden dalam mencuci tangan pada 5 momen sebagai upaya pencegahan infeksi dengan baik dapat menurunakan angka kuman maupun bakteri pada tangan. Hasil penelitian ini juga didukung oleh penelitian yang dilakukan Abdullah dengan hasil bahwa sebagian besar responden di RSUD Haji Makasar mempunyai sikap yang tinggi dalam upaya pencegahan infeksi $(83,1 \%)$ dari 118 responden yang diteliti (13). Seorang dokter muda dikatakan profesional jika memiliki pengetahuan, keterampilan, serta memiliki sikap profesional sesuai kode etik profesi kedokteran. Pengetahuan responden khususnya dokter muda dapat terus meningkat apabila rumah sakit dapat terus meningkatkan kemampuan dengan berbagai pelatihan dan edukasi yang berkesinambungan bagi seluruh karyawan pada semua aspek pencegahan Hospital Acquired Infections (HAls) (14).

Hasil penelitian juga menunjukan bahwa masih adanya responden yang kurang melakukan upaya pencegahan Hospital Acquired Infections (HAls) yaitu pada momen sebelum ke pasien $(87,19)$, sesudah dari pasien $(82,92 \%)$, dan sesudah kontak dengan lingkungan pasien $(54,87 \%)$. Masih adanya responden yang kurang melakukan upaya pencegahan infeksi sebelum kontak dengan pasien dapat menyebabkan meningkatnya kejadian Hospital Acquired Infections (HAls). Gwarzo Garba mengungkapkan bahwa faktor yang menyebabkan petugas kesehatan tidak mencuci tangan saat tindakan aseptis yaitu petugas kesehatan merasa tugas yang dijalaninya terlalu banyak dan sibuk sehingga beranggapan bahwa tidak melihat atau tidak merasa tangannya kotor saat melakukan Indonesian Journal of Hospital Administration Vol. 2 No.2 
tindakan asepsis (15). Sedangakan Suryoputri mengukapkan bahwa setelah kontak dengan pasien, petugas kesehatan merasa memiliki resiko yang lebih besar tertular penyakit atau terkena infeksi saat setelah kontak dengan pasien dan mempunyai keharusan untuk mencuci tangan (16). Menurut WHO (2010) peningkatan upaya pencegahan Hospital Acquired Infections (HAls) dengan melakukan cuci tangan diperlukan strategi yang multidimensi. Adanya fasilitas yang memadai, program sosilaisasi, sistem reward dan punishment dapat meningkatkan pelaksanaan cuci tangan oleh tenaga kesehatan (17). Pendekatan lain yang dapat dilakukan dengan pelatihan kepada petugas kesehatan secara teratur dan berkala, evaluasi dan umpan balik berupa monitoring, serta adanya sistem pengingat ditempat kerja untuk promosi dan meningkatkan kepedulian petugas kesehatan.

\section{SIMPULAN DAN SARAN}

Karakteristik Responden di Rumah Sakit Putri Hijau Medan Sumatera Utara, sebagian besar berjenis kelamin perempuan dengan usia 24 tahun. Responden di Rumah Sakit Putri Hijau Medan Sumatera Utara melakukan upaya pencegahan infeksi dengan melaksanakan upaya 5 momen mencuci tangan yaitu sebelum dan sesudah ke pasien, sebelum tindakan invasif, sesudah terpapar cairan beresiko serta sesudah kontak dengan lingkungan pasien.

Saran penelitian ini bagi Rumah Sakit Putri Hijau diharapkan terus melakukan upaya perbaikan dengan meningkatkan kepatuhan pelaksanaan cuci tangan untuk mencegah terjadinya Hospital Acquired Infections (HAls) misalnya dengan memberikan reward dan punishment kepada petugas kesehatan dan melakukan pengawasan pelaksanaan cuci tangan oleh petugas kesehatan secara rahasia serta dapat melakukan pelatihan secara rutin terkait upaya pencegahan infeksi melalui cuci tangan yang baik dan benar serta Dokter muda diharapkan lebih dapat menyadari tentang pentingnya untuk melakukan cuci tangan bukan hanya sebagai proteksi terhadap diri sendiri, tetapi untuk proteksi tranmisi infeksi dari satu pasien kepasien yang lain saat dilakukan tindakan kesehatan. Untuk peneliti selanjutnya diharapkan dapat meneliti lebih lanjut terkait faktor-faktor yang mempengaruhi kepatuhan mencuci tangan serta dapat menggunakan metode-metode yang berbeda dalam meneliti kepatuahan mencuci tangan sebagai upaya pencegahan infeksi.

\section{DAFTAR PUSTAKA}

1. Joint Commission International. Standar Akreditasi Rumah Sakit. Jakarta: Gramedia; 2011.

2. Kadi, A. \& Salati SA. Hand Hygiene Practices Among Medical Students. J Interdiscip Perspect Infect Dis [Internet]. 2012; Available from: 
https://www.hindawi.com/journals/ipid/2012/679129/

3. World Health Organization (WHO). Prevention of Hospital Acquired Infections, A Practical Guide [Internet]. Geneva: WHO Press; 2004. Available from: http://apps.who.int/medicinedocs/documents/s16355e/s16355e.pdf. diakses 13

4. Departemen Kesehatan Republik Indonesia. Pedoman Manajerial Pencegahan dan Pengendalian Infeksi di Rumah Sakit dan Fasilitas Kesehatan Lainnya. Jakarta: Departemen Kesehatan RI; 2011.

5. Darmadi. Infeksi Nosokomial Problematika dan Pengendaliannya. Jakarta: Selemba Medika; 2008.

6. Frost \& Sullivan. Hospital Acquired Infection- Trend Across Europe [Internet]. 2010. Available from:http://www.frost.com/prod/servlet/press-release.pag?docid=289174935

7. Broker C. Ensiklopedia Keperawatan. Jakarta: EGC;2009.

8. Cahyani C. Hubungan Jenis Kelamin Dengan Tahap Cuci Tangan Mahasiswa Saat Praktikum di Laboratorium Mikrobiologi Fakultas Kedokteran Sebelas Maret Surakarta. Universitas Sebelas Maret; 2010.

9. Anwar. Teori Perkembangan Kognitif. Jakarta: EGC; 2007.

10. Purwanti E. Hubungan Tingkat Pengetahuan dan Sikap Petugas Kesehatan Dengan Penerapan Teknik Mencuci Tangan Secara Benar. Universitas Gadjah Mada; 2011.

11. Azwar S. Sikap Manusia Teori dan Pengukurannya. Yogyakarta: Pustaka Pelajar Offset; 2009.

12. Setiana D. Pengetahuan, Sikap, Dan Praktik Mahasiswa Fakultas Kedokteran Terhadap Pencegahan Infeksi. Universitas Diponegro; 2011.

13. Abdullah K. Hubungan Pengetahuan, Motivasi, dan Supervisi Dengan Kinerja Pencegahan Infeksi Nosokomial di RSUD Haji Makasar. Universitas Hasanudin Makasar; 2014.

14. Yulianti, Rosyidah dan Haryono W. Penerapan Universal Preacaution Pada Perawat di Bansal Rawat Inap Rumah Sakit PKU Muhammadiyah Yogyakarta. Jurnal Kesehatan Masyarakat. 2011;5(2).

15. Gwarzo Garba. Hand Hygiene Practice Among Healthcare Workers in a Public Hospital in North-Western Nigeria. J Niger Basic Clin Sci. 2018;15(2).

16. Suryoputri. Perbedaan angka Kepatuhan Cuci Tangan Petugas Kesehatan di RSUP Dr. Kariadi. Universitas Diponegoro; 2011.

17. World Health Organization (WHO). Using WHO Hand Hygiene Improvement Tools to Support teh Implementation of National/Subnational Hand Hygiene Campaigns [Internet]. Geneva: WHO; 2010. 